of sowing, and the season for navigation. He goes at great length into the question in his Deipnosophists; and I invite the attention of those who wish to know something as to the early history and influence of the Pleiades to the worls in question.

As Plutarch says that the great feast of Isis was always held at the time "when the Pleiades are most conspicuous," and I found that the month of Athyr, in which it was held, was described as "the shining season of the Pleiades," I sent, in 1865 , a copy of my pamphlet to Prof. C. P. Smyth, before he went to Egypt, and invited his attention to the probability that those stars were in some way indicated by the Great Pyramid.

The recent discovery by Mr. Penrose that the Hecatompedon site of the Parthenon, and other archaic Greek temples were oriented by the Pleiades, lends a new interest to this subject.

This diversity of orientation has had a far wider range than has been supposed, for nearly forty years ago it was noticed in the Mississippi mounds by Squier and Davis; and was long ago detected in several early churches of the south of England, a very remarkable fact, which I think was referred to at the Anthropological Institute. As it greatly surprised and interested me, I made a careful note of it when it was published, which I regret that I cannot now hunt up, as I am preparing to leave lingland for the winter; but as the point cannot have escaped the attention of others, some one among your readers will perhaps be able to give you further information as to it.

NATURE of August 3 I contains an interesting letter on the importance of the study of the date of the birth of Rama by competent astronomers. For several years I have been trying to find out what was the precise time of the year when Kartikeya was born-" The Birth of the War God" does not refer to it. There is a most interesting subject which is new to science, the connection of the Pleiades with the nativity of divine heroes. I think I can at last supply a clue to the Star of Bethlehem (which Kepler imagined to have been a conjunction of planets!) in "the Christmas Stars," of the negroes, and other African races. September 7 . R. G. HallibuRTon.

\section{Early Chinese Observations on Colour Adaptations.}

IT seems of interest to record that the Chinese, neglectful of the sciences as they are nowadays, nevertheless suggested the Darwinian interpretation of animal colours as early as the ninth century A.D.

Twang Ching-Shib, in his Yú-yáng-láh-tsú (Maútion's edition, brok xvii. p. 7 Kyōto, 1697), describes a trap-door spider as follows:- "Whenever rain has fallen, the ground facing my book-room has plenty of the 'tien-tang' (that is, the 'tumblingdefender'). Its nest, commonly so-called, is as deep as an earthworm's hole, and the network is finished in it. The earthy lid of the nest is quite $\epsilon$ ven with the ground, and of the size of elm-samara. The animal turning upside down, guards the lid, and thus watching for the appearance of flies and caterpillars, it readily turns up the lid and catches them. As soon as it retreats the lid is closed again. The lid is coloured like the ground."

A pparently from this and other facts the observer has attained a revelation of the truth, which he expresses thus:- "In general, birds and mammals necessarily conceal forms and shadows by their assimilation with various objects. Consequently, a snake's colour is similar to that of the ground; the hare in the Imperata-grass is unavoidably overlooked, and the hawk's hue agrees with that of the trees."

Twang Ching-Shih was a man of great erudition, and versed in poetry ; he died in the period of $\mathrm{H}$ wi-Cháng ( $84 \mathrm{I}-846$ A.D.), leaving us the work cited above, consisting of thirty books. It is highly commended by Sie Tsái-Kang, a distinguished encyclopædist of the seventeenth century A.D., as one of the two "Crowns of all Miscellanies."

\section{Kumagusu Minakata.}

15, Blithfield-street, Kensington, September 26.

\section{A Remarkable Meteor.}

A METEOR of surpassing brilliancy and great size was seen here on the Ist inst., just before 10 p.m. The course seemed to he from westwards towards the north-east. The meteor was of a vivid blue colour, and it lighted with its splendour the whole visible horizon. In a clear blue sky the harvest moon, on the wane, was at the time shining brightly.

NO. I 250, VOL. 48 ]
On disappearance the blue fiery ball left behind it for some seconds a long luminous trail, like that which follows the flight of a rocket. Travelling apparently at a considerable height, the ball was observed at much about the same time at Llanefjdd, amongst the hills in North Wales. A correspondent writes thence: "Last night (the Ist inst.) I witnessed a remarkable meteor. I always, these moonlight nights, go up the Freilh just before Io p.m. I went up last night; it was just like day (the effect of the moon shining in the clear air of the hills). Just when I was on the top, turning to come down, and looking up the valley, the place suddenly became lit up with a blaze of intense blue light. I thought it was a tremendous lightning flash; but as it lasted too long for that, I looked, and then saw what it was. There was a meteor falling just behind Tan-y-Gurt Mountain, as bright apparently as the sun. It was a globe of flame as large as an ordinary foot. ball, and of a light blue colcur. I saw the ball for about as long as a rocket takes when falling. The ball was very much like an enormous rocket, and afterwards there was an appearance just like a stick falling from the flame. The meteor came from the west, travelled towards the north-east, and fell perpendicularly." My correspondent adds: "The meteor did not shoot from any radiant known to me."

Worcester, October 4 .

\section{J. LLOYD BOZWARD.}

ThIs meteor was distinctly seen at Driffield, East Yorkshire. It proceeded from a point about $45^{\circ}$ altitude in the west, and passed towards south-south-west at an angle of about $40^{\circ}$, disappearing at an altitude of about $20^{\circ}$ in the souch-west Duration two seconds ; slow motion. A trail of yellowish-red sparks appeared on both sides (top and bottom) as it travelled forward. Several letters appear in the Yorkshire Post of the $5^{\text {th }}$ inst. from persons who saw it in Yorkshire.

J. LOVEI.

\section{TERTIARY AND TRIASSIC GASTROPODA OF THE TYROL.}

THOUGH much has already been done for continental palæontology, a great deal still remains to be accomplished. The earlier workers in the field laboured under the disadvantage of having to deal with comparatively scanty material, mostly scattered in private collections over large areas at a time when intercommunication was far from easy. Nowadays these old collections with their type-specimens have for the most part found their way into the museums of the principal cities. Moreover, not only may they freely be examined on the spot, but sometimes, we are glad to know, are allowed, under proper precautions, to be removed for the purpose of comparison with types preserved elsewhere. These altered circumstances and the acquisition of new specimens have not merely aided, but even provoked the revision, rectification, and completion of the labours of bygone times.

The two articles before us are examples-the one of supplementary, the other of both supplementary and revisionary work.

To take them in their order:-

Dr. Dreger's paper is the first of a projected series in which it is intended to treat of the fauna of the tertiary beds at Häring in so far only as it has not already been dealt with. Any conclusions Dr. Dreger may have come to concerning the exact age of these deposits, which Giimbel considered to be the equivalents of our Bembridge and Headon beds, are reserved till the whole of the material has been disposed of.

The fossils are in a very bad state of preservation, being much crushed, distorted, and broken: the more

I "Die Gastropoden von Häring bei Kirchbichl in Tirol." Von Dr. Julius Dreger. (Annalen des K.K. Naturhistorischen Hof ınuseums, Bd. vii. 1892 , pp. II-34; Pls. i.-iv.). "Die Gastropoden der Schichten von St, Cassian der südalpinen T'rias." Von E. Kittl. II. Theil. (Ibid. pp. 35-97, Pls. 5. (Wien: A. Hölder.) 
delicate parts, such as the outer lips, long anterior canals, where such existed, and any spiny projections, are usually missing. With such unsatisfactory material to work upon it is little wonder the author has in many ca se; been unable to come to any definite determination as to the species; indeed in several in tances, most wisely, no specific identification is attempted.

The list given at the end shows i 44 forms, including I 5 which are described as new; but of these some had better have been left unnamed till more perfect examples were forthcoming, whilst in certain instances, such as Voluta stromboid's, one feels sceptical, if any reliance may be placed on the fisure, as to the very determination of the genus. Nor is the description of these new species always adequate: that of Trochus demersus being especially insufficient. One of the figures is that of an interesting example of Xenophora, considered by Dr. Dreger to be very near to, if not identical with, $X$. subextensa, d'Orb. This individual mu it have possessed a somewhat fastidious taste, for in lieu of the ordinary fragment; of shell and other oddments that its kindred usually love to attach to their tenements, it selected for the decoration of its house the fusiform shells of Cerithium and Pleurotom.t, which it disposed radially, attaching them by their apices. This unwonted arrangement is paralleled in a recent example of $X$. pallidula, Reeve, dredsed off the Philippines during the Challenger expedition, the decorative shells being those of Terebra and Pleurotoma.

The nomenclature employed by Dr. Dreger is not in all instances up to that standard of exactitude which the present-day devotees of the law of priority demand, and undoubtedly will bear revision, and so, too, we regret to see will his synonymy. Dr. Dreger's principle of giving in synonymic references the name of the authority cited for the species by the author who is quoted is decidedly the fairest and best system and one which for our part we would gladly see universally adopted. By way of instance a portion of the synonymy of Cassidaria ambigua, Brander is here given, omitting however for sake of brevity the references to the several papers:-

1776. Buccinum ambirsum, Brander, \&c.

1812. Cassis striata, Sow., \&c.

1843. Cassidaria a nbigua, Brander, Nyst, \&c.

1851. Cassis affinis, Pnilippi, \&c.

1854 . ", ," ," E. Beyrich, \&c.

1851. ", ", B:yr., Giimbel, \&c.

r864. ", ", Phil., Giebel, \&c.

1865. ", ambigua, Sol., v. Koenen, \&c.

Unfortunately our author has not been as careful in following out his own system as he should. Moreover the reference to the first description of a species is frequently omitted altogether; the descriptions from Brander's "Fossilia Hantoniensia" are sometimes attri buted, and correctly, to Solander, and sometimes, as in the exanple quoted, to Brander: the synonymy is frequently unduly swollen by references to mere lists such as thit in Güinbel's "Goognostische Beschreibung."

The papir concludes with a ta'ble showing the distribution of the 19 species which are also known to occur in other localities. This is supplementary to the similar table givea by Guinbel (op. cit. Abth. i. pp. 6o9-9).

Turning to the second article, it is needless to remark that the St. Cassian beds must ever remain a source of iuterest to the geologist, not only on account of the remarkable mixture they offer of palæozoic with meso-
zoic forms of life, as evinced by the occurrence of Orthoceras on the one hand and Ammsnites on the other, but als, from the fact that so large a number of fossil species are peculiar to them.

The St. Cassian fauna has been treated monographically by Münster in his "Beiträge zur Petrefacten-
Kunde" (Hft. iv., I $84 \mathrm{I}$ ), by Klipstein in his "Beiträge zur Geologischen Kenntniss der östlichen Alpen" (1 843), and by Laube in a series of papers published in the "Denkschriften der k. k. Akademie der Wissenschaften, Wien," between 1865 and 1870 . Although the last-named palæontologist added very largely to the number of species known, the subject was far from being exhausted, and the accumulation of fresh material has enabled Dr. E. Kittl to still further augment the list of Gastropoda by the addition of many new forms, mostly of small size and many of very great beauty.

The first part of this paper, published last year in the preceding volume of the same serial, contained descriptions of all the species of Scaphopoda and of Gastropoda Prosobranchiata from Patella to Clanculus; the second portion now before us embraces the families represented in these beds between and including the Neritidæ and the Littorinidæ, and introduces two new genera-Palconarica, in Neritidæ, and Pseudoscalites in Tricnotropidæ.

The classification and nomenclature followed, it should be stated, is that adopted by Zittel in his well-known "Handbuch der Palæontologie," and of course shares the merits and demerits of that system. Only in two instances does our author depart from his model. The genus Chilocyclus, Bronn, is restored on the ground that it is distinct from the Cochlearia, Braun, to which Münster had referred the St. Cassian species. In the same way Delphinulopsis, Laube, which has been set aside as embracing forms referable to two genera--Neritopsis and Fossariopsis-is re-established by Kittl for reasons which are too technical to be dwelt on here, but which we confess do not seem entirely satisfactory.

To criticise so elaborate and careful a work as this in detail is, indeed, not possible without seeing the actual specimens, however good the figures and lucid the descriptions may be, and we fear it would sound ungracious when so much is vouchsafed us to wish that some of the new types had been less fragmentary, or to express an opinion, however guardedly, that some of the specimens figured, besides that so acknowledged, convey the impression of being immature and possibly the fry of other species.

The difficulties that have to be contended with in the production of a work of this sort are far from small, and the conscientious palæontologist must frequently be at his wits' ends to decide whether he shall refer a given example, especially if imperfectly preserved, to a known genus from the typical forms of which it differs considerably, or shall incur the odium of adding another name to an already overburdened nomenclature.

Take such an instance as that here afforded by the genus Scalaria (or should we write Scala?). Amongst the species are forms which the synonymy shows were referred by so able a palæontologist as Laube to the very distinct genera Turbo, Trochus, and Turritella! A glance at the figures shows how far these forms depart from those we have been accustomed to associate with the old familiar Wentle-traps, and it is little.wonder that Dr. Kittl suggests the desirability of establishing a new subgeneric name for some of the St. Cassian species: we think he would be justified in even founding a new genus to receive them.

The plates that accompany this paper are admirable bits of drawing, but the figures would in most instances have been more satisfactory for working purposes had more of them been enlarged, and those that are enlarged yet further magnified. The double numeration of these plates is, moreover, both clumsy and unnecessary.

It is very interesting to observe in how many of the species of Naticopsis the colour markings seem to have been preserved, nor is this the less remarkable because nstances of a similar description from yet older formitions are on record. 